Research Article

\title{
PERFORMANCE ANALYSIS OF COOLING SYSTEM WITH HORIZONTAL TYPE GROUND SOURCE HEAT PUMP FOR DIYARBAKIR CONDITIONS
}

\author{
Fatih KOÇYİĞİT ${ }^{1^{*}}$
}

In this study, the performance of the horizontal type ground source heat pump cooling system in the summer was analyzed for cooling the testing area with a size of $9 \times 8 \times 2.8 m$ in Diyarbakur province with a warm climate. Energy and exergy analysis was applied to the system and system units by examining the results obtained in the summer in the evaluated system. The monthly and seasonal mean values of the data in the summer (01.06.2018 / 30.08.2018) were taken for 11 node points determined in the installed system. In the energy analysis performed with the results obtained, it was calculated that the energy loss in the system was $2.499 \mathrm{~kW}$ and the energy efficiency $76.86 \%$. For the system units, the unit operating with the lowest energy efficiency was determined as the compressor. According to exergy analysis applied to the system, it was calculated that the exergy loss of the system was $2.150 \mathrm{~kW}$ and the second law efficiency was 20.70\%. The compressor was also determined as the unit with the highest exergy loss in the system. Compressor should be prioritized for improvement studies to be planned according to both energy and exergy analysis results. The COP value of the system was found to be 4.05, and it was determined that the system, the use of which was examined in the summer, could be used for Diyarbakir province.

Key words: Groud Source Heat Pump, Horizontal Type Ground Source Heat Pump, Energy Analysis, Exergy Analysis,

\section{Introduction}

Due to gradual reduction of energy resources and the rapid increase in energy prices nowadays, efficient use of energy has become a necessity. The increase in harmful effects of fossil fuel-powered systems on the environment along with the increasing energy needs in parallel with the growing population has caused users to search for different solutions with the developing technology [1]. In this context, ensuring energy efficiency has become very important for the efficient use of energy and the energy economy. Most of the energy produced is consumed in the heating and cooling of the houses. Many studies are carried out to use energy more efficiently in the world and alternative solutions are sought for conventional air conditioning systems. Heat pumps are preferred in many applications and are increasingly used due to their high usage efficiency and environmentally friendly technologies in compared to commonly used conventional air conditioning systems. Ground source heat pump systems are mainly preferred for the air conditioning of the houses. In previous studies, it was indicated that the

\footnotetext{
${ }^{1}$ Department of Airframe and Powerplant, School of Civil Aviation, University of Dicle, Turkey, TR (fatih.kocyigiticle.edu.tr) https://orcid.org/0000-0001-6383-3163 
energy consumed in the air conditioning of the houses could be reduced with the help of heat pumps, and thus, energy could be used more efficiently. In the literature, many studies were carried out on the use and evaluation of heat pumps for air conditioning. Kincay and Temir[2] carried out a study on the dimensioning of vertical type ground source heat pump system for a villa. Akbulut et al. [3] performed the energy and exergy analysis of the integrated wall cooling system with vertical type ground source heat pump in the Renewable Energy House at Yildız Technical University. Furthermore, Akbulut et al. [4] performed the exergoeconomic and environmental analyses of the integrated wall cooling system with vertical type ground source heat pump used in the cooling season. Nevertheless, Akbulut et al. [5] performed the exergy, exergoeconomic and environmental analysis of the integrated wall heating system with a vertical ground source heat pump in the winter for the specified testing area. In their study, they indicated that the vertical type ground source heat pump system could be used for Istanbul province. Ünal et al. [6] performed the energy, exergy and exergoeconomic analysis of the solar powered vertical type ground source heat pump system for the heating season in Midyat district of Mardin province. In their study, they reported that it was appropriate to use the solar powered vertical type ground source heat pump system in Mardin province. Ünal and Temir [7] performed the exergoeconomic analysis of the cooling system with a ground source heat pump for the testing area they determined in Mardin province. Hepbaşl1 et al. [8] conducted experimental studies to examine the performance of a vertical type ground source heat pump with a depth of $50 \mathrm{~m}$ in order to meet the air conditioning needs of a 65 $\mathrm{m}^{2}$ room in İzmir province. Nagano et al. [9] conducted studies to improve the design of the ground source heat pump in Sapporo. In their study, they also compared $\mathrm{CO}_{2}$ emission data and determined the payback period for the specified region of the system they designed as 9-14 years. Niğdelioğlu [10] evaluated the system performance with parameters affecting a ground source heat pump system used for cooling in the summer in Kütahya province. As a result of the experimental analyses, they determined that the mean COP value of the ground source heat pump system used was 3.41, and they indicated that the system could be used for Kütahya province. Özgener and Hepbaşl1 [11] conducted studies on performance evaluation by modeling the ground source heat pump system. In their studies, they performed the performance analysis of the vertical type and horizontal type ground source heat pump systems that they modelled, and they compared the systems with the results obtained. Karabacak et al. [12] conducted an experimental investigation to determine the performance of the vertical type ground source heat pump system in the summer in Denizli. In their study, the COP values were obtained as 3.14.8 for the system investigated. Zhai and Yang [13] experimentally analyzed the ground source heat pump system with a cooling capacity of $500 \mathrm{~kW}$ in Shanghai. According to the results of the analyses, they determined that the system to be installed would have a two-year payback period. In his study, Kılıç[14] designed a ground source heat pump system by using two different methods to meet both the heating and cooling needs of a two-storey villa in Adana. He analyzed the designed system for both summer and winter seasons. Ünal and Akan [15] performed the energy and exergy analysis of the solar powered vertical type ground source heat pump in Mardin province depending on the experimental data obtained. In their analysis, they indicated that the system unit with the highest exergy loss rate was the compressor. Esen [16] designed a vertical type ground source heat pump system with drilling wells of different depths, $30 \mathrm{~m}, 60 \mathrm{~m}$ and $90 \mathrm{~m}$, to be used in the garden of a house in the summer and winter seasons in Elazığ. He compared the performance of three systems by using different artificial neural network methods. With the results obtained in the summer and winter seasons, he indicated that the ground source heat pump system with a depth of $90 \mathrm{~m}$ had the highest system performance. Is1k et al. [17] an analysis was made according to the second law of thermodynamics, to an existing thermal power 
plant that uses lignite fuel. In their studies, useful power, reversible power and irreversibility amounts were determined for the turbine from the power plant components forming the system and the overall efficiency of the system was calculated

In this study, unlike the studies in the literature, a horizontal type ground source heat pump cooling system was built Diyarbakır province Bismil county, which has a warm climate and provides its needs for air conditioning mainly with fossil-based fuels. Depending on the results of the experimental studies conducted during the summer in the system built, energy and exergy analysis was applied to the system and its units and the usability of the system analyzed in this county was evaluated.

\section{Material And Method}

In this study, a horizontal type ground source heat pump was used for testing in order to meet the cooling needs of a 9x8x2.8 m ground floor of a workplace in Diyarbakır, Bismil county, and a thermodynamic analysis of the system was made for the summer season. The test facility has nine units consisting of compressor, condenser, evaporator, throttle valve, two circulation pumps, horizontal type underground heat exchanger, accumulation tank and fan coil panel and 11 node points where measurements are taken. The test facility is used to meet the cooling need of the location. In addition, temperature measurements were made with PT-100 type thermocouples (sensitivity $\pm 1^{\circ} \mathrm{C}$ ) placed in 11 node points determined in the system and the flow rates of the fluid were measured with GT-TD-20 type $3 / 4$ " PVC turbine flowmeters (sensitivity 1\%) placed after the pumps and the refrigerant fluid flow was measured from the controller of the heat pump. Pressure measurements in the system were made with the help of manometers on the heat pump. The data obtained by the measurements were recorded instantaneously with the help of 24 channel datalogger. The electricity meter connected to the network is used for the measurements of the electricity consumption of the compressor, pumps and fan coil panel. The data obtained were averaged over a 3-month period determined for the summer season, and evaluation was performed for the system and its units. The general scheme of the system used for cooling is presented in Figure 1. During the theoretical operation of the system, the fan coil panel transfers the heat it extracts from the space (ËFP) to the evaporator. Then, heat transfer fluid is converted into gas with the heat extracted with evaporator $\left(\dot{E}_{\mathrm{L}}\right)$. When the heat transfer fluid is in gaseous state, its temperature and pressure are increased by the compression process performed in the compressor and transported to the condenser. The heat generated during the condensation process in the condenser $\left(\dot{\mathrm{E}}_{\mathrm{H}}\right)$ is transferred to the underground circuit $\left(\dot{\mathrm{E}}_{\mathrm{G}}\right)$. Then the refrigerant passes through the throttle valve and the cycle continues in this way. 


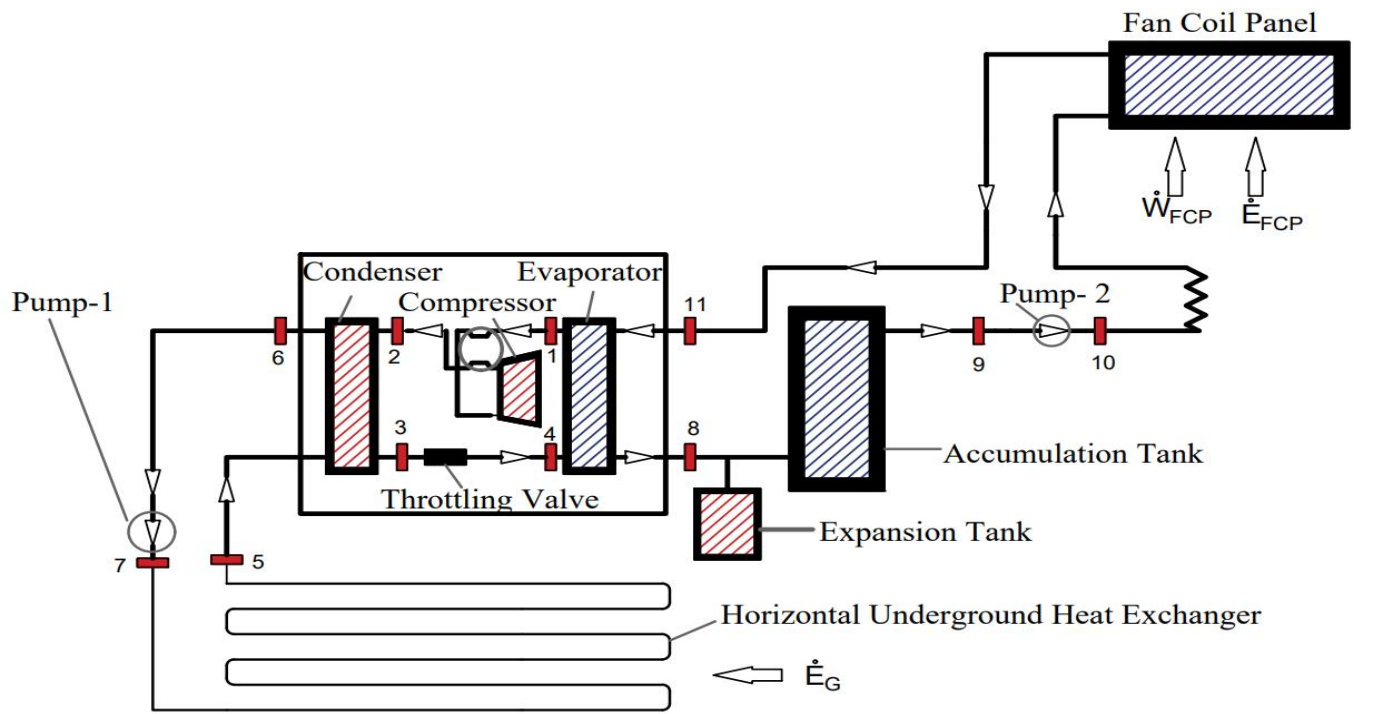

(a)

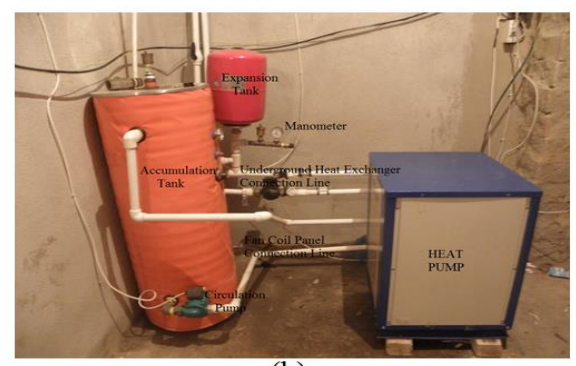

(b)

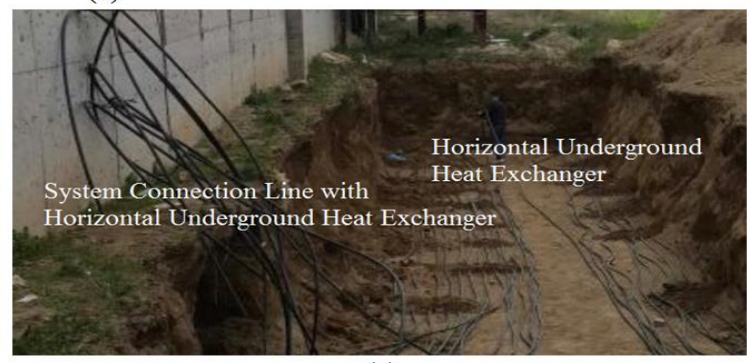

(c)

Figure 1. a) Flow chart of the system in the summer season b) Heat pump room c) Horizontal underground heat exchanger

The information about the features and assumptions of the system used in the experimental study are presented below:

- The system analyzed is a system that complies with the continuous-flow open system model. The cooling capacity of the horizontal type ground source Restherma brand heat pump used in the system to meet the cooling needs of the test site is given as $9 \mathrm{~kW}$ in the catalog data.

- For the horizontal type underground heat exchanger, $15 \mathrm{~m}$ long and $10 \mathrm{~m}$ wide, $150 \mathrm{~m}^{2}$ area was laid horizontally to a depth of $2 \mathrm{~m}$. A total of $730 \mathrm{~m}$ long PE 80 type pipe was used for the horizontal type underground heat exchanger. Since the underground heat exchanger was completely surrounded by soil, heat losses in this unit were neglected.

- The heat exchanger I functions as an evaporator. The heat exchanger II functions as a condenser. Scroll type Copeland brand compressor was used in the system. There was no enthalpy loss in the throttle valve $\left(h_{3}=h_{4}\right)$. The accumulation tank used has a capacity of 200 liters. Heat loss occurred although the accumulation tank had insulation. Accumulation tank was used as a balance tank functioning for cold water storage in the system. In the system, cassette floor type 2 pipe AE 400 model fan coil panel is used.

- Underground heat exchanger in the system, water in the fan coil panel, and refrigerant R407C in the heat pump were used as the heat carrier fluid. While the properties of the water were determined by the EES package program, the properties of the $\mathrm{R} 407 \mathrm{C}$ were determined with the help of the Refprop package program.

- In the exergy analysis, reference environmental values were used as $\mathrm{T}_{0}=0.01^{\circ} \mathrm{C}$ and $\mathrm{P}_{0}=1 \mathrm{bar}$. 


\subsection{Analyses}

While the first law of thermodynamics is taken as a basis in energy analyses, both the first and second laws of thermodynamics are used together in exergy analyses. The energy balance for the examined system, which fits a continuous-flow open system, is expressed by Equation 1 .

$$
\dot{\mathrm{E}}=\mathrm{H}+\mathrm{KE}+\mathrm{PE}=\dot{\mathrm{m}}\left[\mathrm{h}+\frac{\mathrm{v}^{2}}{2}+\mathrm{g} \cdot \mathrm{z}\right]
$$

In the system analyzed, the height change was zero, and thus, potential energy was considered zero. Kinetic energy was considered zero since the energy change due to the velocity change of the fluid was very small compared to the internal energy. When potential energy and kinetic energy are neglected, the energy balance is presented by Equation 2 .

$$
\dot{\mathrm{E}}=\dot{\mathrm{m}} \cdot \mathrm{h}
$$

In this study, the expression of energy loss is given by Equation 3 .

$$
\dot{\mathrm{E}}_{\text {loss }}=\dot{\mathrm{E}}_{\text {in }}-\dot{\mathrm{E}}_{\text {out }}
$$

The efficiency of the system or system element (COP: Coefficient of Performance) was found by dividing the value desired to be obtained by the value required to be spent for this purpose.

$$
\eta=\frac{\text { value desired to be obtained }}{\text { value required to be spent }}
$$

The most useful work that a system can do in a given state is defined as exergy (availability). The term exergy is a feature related to the states of the system and the environment. In this study, only physical exergy equations were used. Physical exergy is given by Equation 5 .

$$
\dot{\mathrm{Ex}}=\dot{\mathrm{m}} . \Psi=\dot{\mathrm{m}}\left[\left(\mathrm{h}-\mathrm{h}_{0}\right)-\mathrm{T}_{0}\left(\mathrm{~s}-\mathrm{s}_{0}\right)\right]
$$

Furthermore, the exergy of the work transferred at the system boundaries is equal to its own value. In this context, the exergy expression of the work is presented by Equation 6 . The exergy value of the transferred heat is calculated by multiplying its value by the Carnot Efficiency calculated by evaluating the temperature at the system boundary and the ambient temperature. The exergy expression of the transferred heat is presented by Equation 7 .

$$
\begin{aligned}
& \dot{\mathrm{E} \mathrm{x}_{\mathrm{W}}}=\mathrm{W} \\
& \dot{\mathrm{E} \mathrm{x}_{\mathrm{Q}}}=\mathrm{Q}\left(1-\frac{\mathrm{T}_{0}}{\mathrm{~T}}\right)
\end{aligned}
$$

In this study, exergy loss, in other words, exergy destruction is given by Equation 8 .

$$
\dot{\mathrm{E}} \mathrm{x}_{\text {loss }}=\dot{\mathrm{E}} \mathrm{x}_{\text {in }}-\dot{\mathrm{E}} \mathrm{x}_{\mathrm{out}}=\dot{\mathrm{E}} \mathrm{x}_{\text {destruction }}
$$


In this study, after the exergy loss in each unit of a system was determined, the exergy loss rate was achieved by proportioning the exergy loss of the relevant unit to the exergy loss in the whole system. The exergy loss rate is presented by Equation 9

$$
\mathrm{d}_{\mathrm{k}}=\frac{\dot{\mathrm{E}} \mathrm{x}_{\text {loss,unit }}}{\dot{\text { Ex} \text { loss,system }}}
$$

The second law efficiency was defined as expressed in Equation 10 according to the fuel-product principle.

$$
\eta_{\text {II }}=\frac{\dot{\text { Ex}} \dot{x}_{\text {product }}}{\dot{E x}_{\text {fuel }}}
$$

The equations used in the energy and exergy analysis performed in the study are presented in Table1.

\begin{tabular}{|c|c|c|}
\hline Unit & Energy Balances & Exergy Balances \\
\hline \multirow{4}{*}{ System } & $\dot{\mathrm{E}}_{\text {loss }}=\dot{\mathrm{m}}_{\mathrm{FCP}} \mathrm{h}_{\mathrm{FCP}}+\dot{\mathrm{W}}_{\mathrm{in}}-\dot{\mathrm{m}}_{\mathrm{G}} \mathrm{h}_{\mathrm{G}}$ & $\dot{\mathrm{E}} \mathrm{x}_{\text {loss }}=\dot{\mathrm{m}}_{\mathrm{FCP}} \Psi_{\mathrm{FCP}}+\dot{\mathrm{W}}_{\mathrm{in}}-\dot{\mathrm{m}}_{\mathrm{G}} \Psi_{\mathrm{G}}$ \\
\hline & $\dot{\mathrm{W}}_{\text {system }}=\mathrm{W}_{\mathrm{in}}=\dot{\mathrm{W}}_{\mathrm{p} 1}+\dot{\mathrm{W}}_{\text {comp }}+\dot{\mathrm{W}}_{\mathrm{p} 2}+\dot{\mathrm{W}}_{\mathrm{FCP}}$ & $\dot{\mathrm{W}}_{\text {system }}=\mathrm{W}_{\mathrm{in}}=\dot{\mathrm{W}}_{\mathrm{p} 1}+\dot{\mathrm{W}}_{\text {comp }}+\dot{\mathrm{W}}_{\mathrm{p} 2}+\dot{\mathrm{W}}_{\mathrm{FCP}}$ \\
\hline & $\operatorname{cop}=\frac{\dot{E}_{G}}{E^{2}}$ & Ė $_{\text {product }}$ \\
\hline & $\dot{\mathrm{W}}_{\text {system }}$ & IIII Ė $\mathrm{x}_{\text {fuel }}$ \\
\hline Compressor & $\dot{\mathrm{E}}_{\text {loss }}=\dot{\mathrm{m}}_{1} \mathrm{~h}_{1}+\dot{\mathrm{W}}_{\text {comp }}-\dot{\mathrm{m}}_{2} \mathrm{~h}_{2}$ & $\dot{\mathrm{E}} \mathrm{x}_{\text {loss }}=\dot{\mathrm{m}}_{1} \Psi_{1}+\dot{\mathrm{W}}_{\text {comp }}-\dot{\mathrm{m}}_{2} \Psi_{2}$ \\
\hline Condenser & $\dot{\mathrm{E}}_{\text {loss }}=\dot{\mathrm{m}}_{2} \mathrm{~h}_{2}+\dot{\mathrm{m}}_{5} \mathrm{~h}_{5}-\dot{\mathrm{m}}_{3} \mathrm{~h}_{3}-\dot{\mathrm{m}}_{6} \mathrm{~h}_{6}$ & $\dot{\mathrm{E}} \mathrm{x}_{\mathrm{loss}}=\dot{\mathrm{m}}_{2} \Psi_{2}+\dot{\mathrm{m}}_{5} \Psi_{5}-\dot{\mathrm{m}}_{3} \Psi_{3}-\dot{\mathrm{m}}_{6} \Psi_{6}$ \\
\hline Evaporator & $\dot{\mathrm{E}}_{\text {loss }}=\dot{\mathrm{m}}_{4} \mathrm{~h}_{4}+\dot{\mathrm{m}}_{11} \mathrm{~h}_{11}-\dot{\mathrm{m}}_{8} \mathrm{~h}_{8}-\dot{\mathrm{m}}_{1} \mathrm{~h}_{1}$ & $\dot{\mathrm{E}} \mathrm{x}_{\text {loss }}=\dot{\mathrm{m}}_{4} \Psi_{4}+\dot{\mathrm{m}}_{11} \Psi_{11}-\dot{\mathrm{m}}_{1} \Psi_{1}-\dot{\mathrm{m}}_{8} \Psi_{8}$ \\
\hline Throttling Valve & $\dot{\mathrm{E}}_{\text {loss }}=\dot{\mathrm{m}}_{3} \mathrm{~h}_{3}-\dot{\mathrm{m}}_{4} \mathrm{~h}_{4}$ & $\dot{\mathrm{Ex}}_{\mathrm{loss}}=\dot{\mathrm{m}}_{3} \Psi_{3}-\dot{\mathrm{m}}_{4} \Psi_{4}$ \\
\hline Pump 1 & $\dot{\mathrm{E}}_{\text {loss }}=\dot{\mathrm{m}}_{6} \mathrm{~h}_{6}+\dot{\mathrm{W}}_{\mathrm{p} 1}-\dot{\mathrm{m}}_{7} \mathrm{~h}_{7}$ & $\dot{\mathrm{Ex}}_{\mathrm{loss}}=\dot{\mathrm{m}}_{6} \Psi_{6}+\dot{\mathrm{W}}_{\mathrm{p} 1}-\dot{\mathrm{m}}_{7} \Psi_{7}$ \\
\hline $\begin{array}{l}\text { Underground } \\
\text { Heat Exchanger }\end{array}$ & $\dot{\mathrm{E}}_{\text {loss }}=\dot{\mathrm{m}}_{7} \mathrm{~h}_{7}-\dot{\mathrm{E}}_{\mathrm{G}}-\dot{\mathrm{m}}_{5} \mathrm{~h}_{5}$ & $\dot{\mathrm{E}} \mathrm{x}_{\text {loss }}=\dot{\mathrm{m}}_{7} \Psi_{7}-\dot{\mathrm{Ex}}_{G}-\dot{\mathrm{m}}_{5} \Psi_{5}$ \\
\hline Pump 2 & $\dot{\mathrm{E}}_{\text {loss }}=\dot{\mathrm{m}}_{9} \mathrm{~h}_{9}+\dot{\mathrm{W}}_{\mathrm{p} 2}-\dot{\mathrm{m}}_{10} \mathrm{~h}_{10}$ & $\dot{\mathrm{E}} \mathrm{x}_{\text {loss }}=\dot{\mathrm{m}}_{9} \Psi_{9}+\dot{\mathrm{W}}_{\mathrm{p} 2}-\dot{\mathrm{m}}_{10} \Psi_{10}$ \\
\hline Acc. Tank & $\dot{\mathrm{E}}_{\text {loss }}=\dot{\mathrm{m}}_{8} \mathrm{~h}_{8}-\dot{\mathrm{m}}_{9} \mathrm{~h}_{9}$ & $\dot{\mathrm{E}} \mathrm{x}_{\text {loss }}=\dot{\mathrm{m}}_{8} \Psi_{8}-\dot{\mathrm{m}}_{9} \Psi_{9}$ \\
\hline Fan Coil Panel & $\dot{\mathrm{E}}_{\text {loss }}=\dot{\mathrm{m}}_{10} \mathrm{~h}_{10}+\dot{\mathrm{E}}_{\mathrm{FCP}}+\dot{\mathrm{W}}_{\mathrm{FCP}}-\dot{\mathrm{m}}_{11} \mathrm{~h}_{11}$ & $\dot{\mathrm{Ex}}_{\mathrm{loss}}=\dot{\mathrm{m}}_{10} \Psi_{10}+\dot{\mathrm{Ex}}_{\mathrm{FCP}}+\dot{\mathrm{W}}_{\mathrm{FCP}}-\dot{\mathrm{m}}_{11} \Psi_{11}$ \\
\hline
\end{tabular}

Table 1. Equations Used in Thermodynamic Analysis

The mean flow, temperature and pressure values measured at the node points determined in the summer, the enthalpy and entropy values, and the energy and exergy values obtained with the help of determined equations are presented in Table 2. 
Table 2. Values Obtained for the Node Points in the Summer

\begin{tabular}{lccccccccccc}
\hline Node Number & $\mathbf{1}$ & $\mathbf{2}$ & $\mathbf{3}$ & $\mathbf{4}$ & $\mathbf{5}$ & $\mathbf{6}$ & $\mathbf{7}$ & $\mathbf{8}$ & $\mathbf{9}$ & $\mathbf{1 0}$ & $\mathbf{1 1}$ \\
\hline Mass Flow (kg/s) & 0.041 & 0.041 & 0.041 & 0.041 & 0.330 & 0.330 & 0.330 & 0.210 & 0.210 & 0.210 & 0.210 \\
Pressure (bar) & 4.90 & 11.80 & 11.80 & 4.90 & 1.65 & 1.65 & 1.65 & 1.53 & 1.53 & 1.53 & 1.53 \\
Temperature ( $\left.{ }^{\mathbf{C}} \mathbf{C}\right)$ & 8.09 & 50.48 & 22.63 & 2.26 & 20.48 & 26.32 & 26.34 & 13.75 & 14.28 & 14.31 & 25.12 \\
Enthalpy (kj/kg) & 422.38 & 444.42 & 227.61 & 227.61 & 85.682 & 110.71 & 110.84 & 59.982 & 60.169 & 60.312 & 105.58 \\
Entropy (kj/kgK) & 17.985 & 18.149 & 11.095 & 11.096 & 0.303 & 0.386 & 0.386 & 0.206 & 0.208 & 0.209 & 0.366 \\
Energy Rate (kW) & 17.318 & 18.221 & 9.332 & 9.332 & 28.275 & 36.534 & 36.577 & 12.596 & 12.635 & 12.666 & 22.172 \\
Exergy Rate (kW) & 6.755 & 7.475 & 6.486 & 6.485 & 0.976 & 1.754 & 1.797 & 0.788 & 0.713 & 0.685 & 1.186 \\
\hline
\end{tabular}

In addition to the values given in Table 2, the power consumed by the compressor in the winter season is $1.705 \mathrm{~kW}$, the power consumed by each of the circulation pumps is $0.048 \mathrm{~kW}$ and the power consumed by the fan coil panel is $0.250 \mathrm{~kW}$. In addition, the heat transferred to the soil is determined to be $8.302 \mathrm{~kW}$ and the exergy value is $0.561 \mathrm{~kW}$, the heat drawn from the experimental area with the fan coil panel is $8.750 \mathrm{~kW}$ and the exergy value is $0.660 \mathrm{~kW}$. ( $\dot{\mathrm{W}}_{\mathrm{komp}}=1.705 \mathrm{~kW}, \dot{\mathrm{W}}_{\mathrm{P} 1}=0.048 \mathrm{~kW}, \dot{\mathrm{W}}_{\mathrm{P} 2}=$ $0.048 \mathrm{~kW}, \dot{\mathrm{W}}_{\mathrm{FCP}}=0.250 \mathrm{~kW}, \dot{\mathrm{E}}_{\mathrm{G}}=8.302 \mathrm{~kW}, \dot{\mathrm{E}}_{\mathrm{FCP}}=8.750 \mathrm{~kW}, \dot{\mathrm{EX}}_{\mathrm{XG}}=0.561 \mathrm{~kW}, \dot{\mathrm{E}}_{\mathrm{XFCP}}=0.660 \mathrm{~kW}$ )

For the summer season. the energy analysis of the system units was performed by using the equations presented in Table 1 depending on the values in Table 2. The results of the energy analysis performed for the system and its units are presented in Table 3.

Table 3. Energy analysis results for the system and its units in the summer.

\begin{tabular}{lcccccccccc}
\hline Unit & System & Comp. & Cond. & Evap. & $\begin{array}{c}\text { Throtling } \\
\text { Valve }\end{array}$ & Pump-1 & UHE & Pump-2 & $\begin{array}{c}\text { Acc. } \\
\text { Tank }\end{array}$ & $\begin{array}{c}\text { Fan Coil } \\
\text { Panel }\end{array}$ \\
\hline$\dot{\mathbf{E}}_{\text {In }}(\mathbf{k W})$ & 10.801 & 19.023 & 46.496 & 31.504 & 9.332 & 36.582 & 36.577 & 12.683 & 12.596 & 21.666 \\
$\dot{\mathbf{E}}_{\text {out }}(\mathbf{k W})$ & 8.302 & 18.221 & 45.866 & 29.914 & 9.332 & 36.577 & 36.577 & 12.666 & 12.635 & 22.172 \\
$\dot{\mathbf{E}}_{\text {loss }}(\mathbf{k W})$ & 2.499 & 0.801 & 0.630 & 1.590 & 0.000 & 0.005 & 0.000 & 0.018 & -0.039 & -0.506 \\
$\dot{\mathbf{E}}_{\text {fuel }}(\mathbf{k W})$ & 10.801 & 1.705 & 8.889 & 9.576 & 9.332 & 0.048 & 8.302 & 0.048 & 12.635 & 9.756 \\
$\dot{\mathbf{E}}_{\text {product }}(\mathbf{k W})$ & 8.302 & 0.904 & 8.259 & 7.986 & 9.332 & 0.043 & 8.302 & 0.030 & 12.596 & 8.750 \\
$\boldsymbol{\eta ( \% )}$ & 76.86 & 53.00 & 92.91 & 83.40 & 100.00 & 89.38 & 100.00 & 62.56 & 99.69 & 89.69 \\
\hline
\end{tabular}

The values of energy loss amounts along with the energy input and output energy for the system and its units are presented in Table 3. Furthermore, fuel energy amount and product energy amount values of the system and its units and the energy efficiency of the system and system units obtained from these values are also presented. As a result of the analysis, the amount of energy loss in the whole system was determined to be $2.499 \mathrm{~kW}$. The energy efficiency of the system was achieved as $76.86 \%$. According to the results presented in Table 3, the energy efficiency value of the compressor was determined as the unit with the lowest efficiency of the system by $53.00 \%$. Energy loss of system units in the summer is given in Figure 2.The monthly distribution of the amount of energy loss observed in the system for the summer season is presented in Figure 3. 


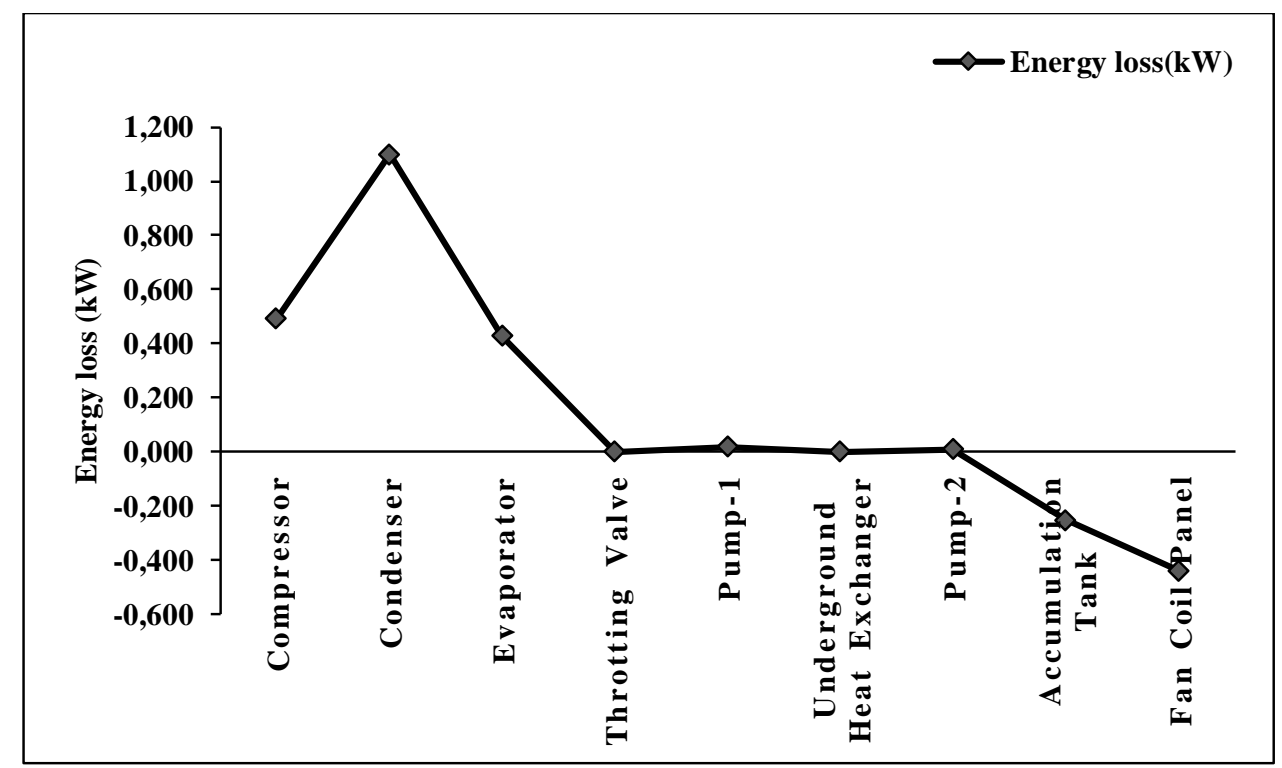

Figure 2. Distribution of energy loss in the system to the system units in the summer.

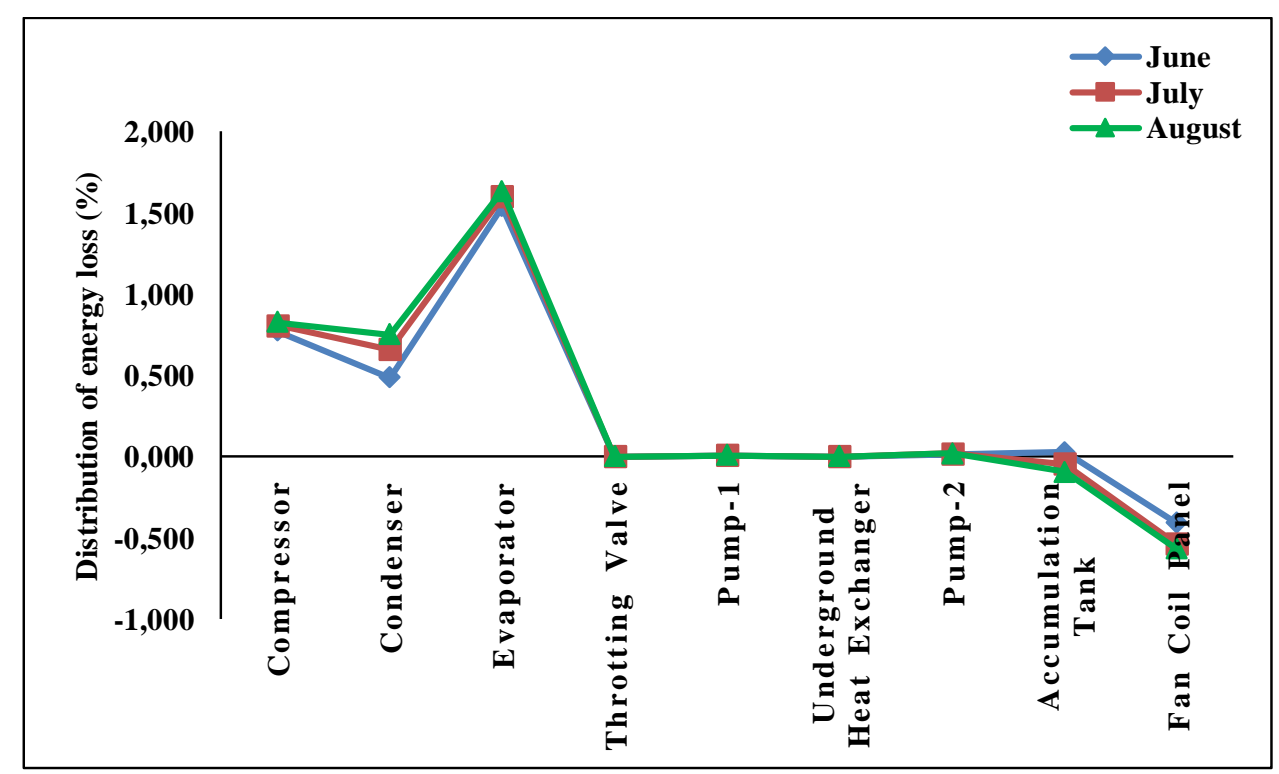

Figure 3. Monthly distribution of the energy loss in the system to the system units in the summer season.

In the assumptions and calculations made for system units in Figure 3, evaporator, compressor, condenser and fan coil panel energy, respectively, were determined as the units with high saving potential. The maximum energy loss for the summer season in the system was determined in the evaporator and compressor by $1.590 \mathrm{~kW}$ and $0.801 \mathrm{~kW}$, respectively. In the energy analyses, no energy loss was observed in the underground heat exchanger and throttle valve. Because it was accepted that there was no heat loss in these units. In the summer, there was an average of $0.506 \mathrm{~kW}$ energy gain for the Fan Coil Panel and $0.039 \mathrm{~kW}$ energy gain for the accumulation tank. The energy analysis results obtained for the summer season of the horizontal type ground source cooling system are presented in Table 4.

Table 4. Monthly energy analysis results for the summer season.

\begin{tabular}{lcccc}
\hline Months worked & June & July & August & Average \\
\hline$\dot{\mathbf{W}}_{\text {comp. }}(\mathbf{k W})$ & 1.63 & 1.73 & 1.76 & 1.70 \\
$\dot{\mathbf{W}}_{\text {system }}(\mathbf{k W})$ & 1.98 & 2.08 & 2.11 & 2.05 \\
COP $_{\text {system }}$ & 4.16 & 4.04 & 3.95 & 4.05 \\
COP & 5.05 & 4.76 & 4.71 & 4.84 \\
\hline
\end{tabular}


According to the results presented in Table 4, it was determined that the average amount of energy consumed by the horizontal type ground source heat pump supported evaporative cooling system in the summer was $2.05 \mathrm{~kW}$, the average amount of energy consumed by the compressor was $1.70 \mathrm{~kW}$ and the mean COP value of the heat pump was 4.84 .

For the summer season, the exergy analysis of the system units was performed by means of the equations in Table 1 with the values presented in Table 2 . The exergy analysis results for the system and its units are presented in Table 5.

Table 5. Exergy analysis results of the system units in the summer.

\begin{tabular}{|c|c|c|c|c|c|c|c|c|c|c|}
\hline Unit & System & Comp. & Cond. & Evap. & $\begin{array}{c}\text { Throtling } \\
\text { Valve }\end{array}$ & Pump-1 & UHE & Pump-2 & $\begin{array}{c}\text { Acc. } \\
\text { Tank }\end{array}$ & $\begin{array}{c}\text { Fan Coil } \\
\text { Panel }\end{array}$ \\
\hline$\dot{E}_{\mathbf{x}_{\mathbf{n}}}(\mathbf{k W})$ & 2.711 & 8.460 & 8.451 & 7.671 & 6.486 & 1.802 & 1.797 & 0.761 & 0.788 & 1.345 \\
\hline$\dot{E}_{x_{o u t}}(\mathbf{k W})$ & 0.561 & 7.475 & 8.239 & 7.543 & 6.485 & 1.797 & 1.537 & 0.685 & 0.713 & 1.186 \\
\hline$\dot{E}_{\mathbf{X}} \operatorname{loss}(\mathbf{k})$ & 2.150 & 0.985 & 0.212 & 0.127 & 0.001 & 0.005 & 0.259 & 0.075 & 0.075 & 0.159 \\
\hline$\dot{E}_{\mathbf{x} f u e l}(\mathbf{k W})$ & 2.711 & 1.705 & 0.989 & 0.398 & 6.486 & 0.048 & 0.821 & 0.048 & 0.788 & 0.660 \\
\hline$\dot{E}_{x p r o d u c t}(\mathbf{k W})$ & 0.561 & 0.720 & 0.778 & 0.270 & 6.485 & 0.043 & 0.561 & 0.027 & 0.713 & 0.501 \\
\hline$\eta_{\mathrm{II}}(\%)$ & 20.70 & 42.228 & 78.60 & 68.00 & 99.98 & 89.38 & 68.38 & 56.94 & 90.43 & 75.86 \\
\hline
\end{tabular}

Exergy values of the system units in the summer season are given in Figure 4. The monthly exergy loss distribution of the system units for the summer season is presented in Figure 5. When this table is evaluated, system units can be compared.

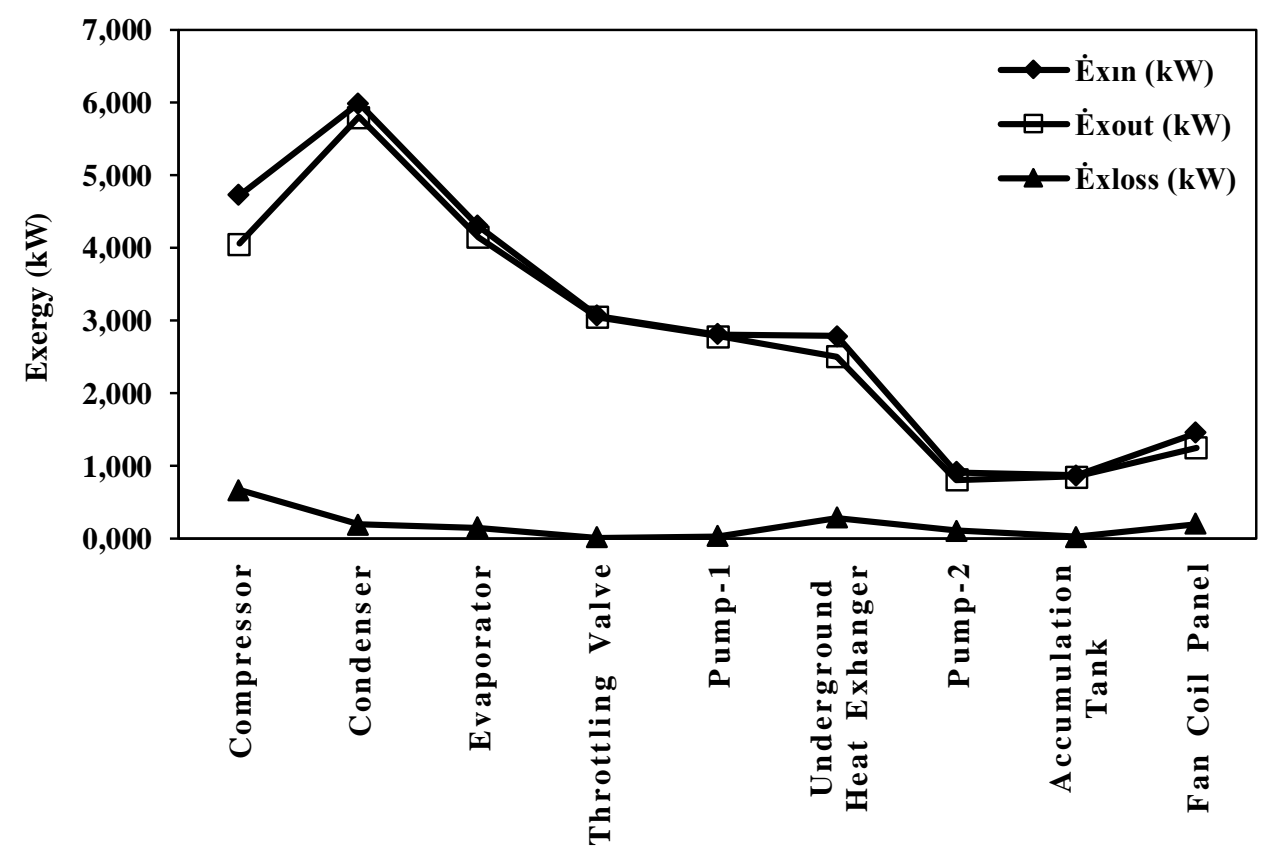

Figure 4. Exergy values of system units in the summer season. 


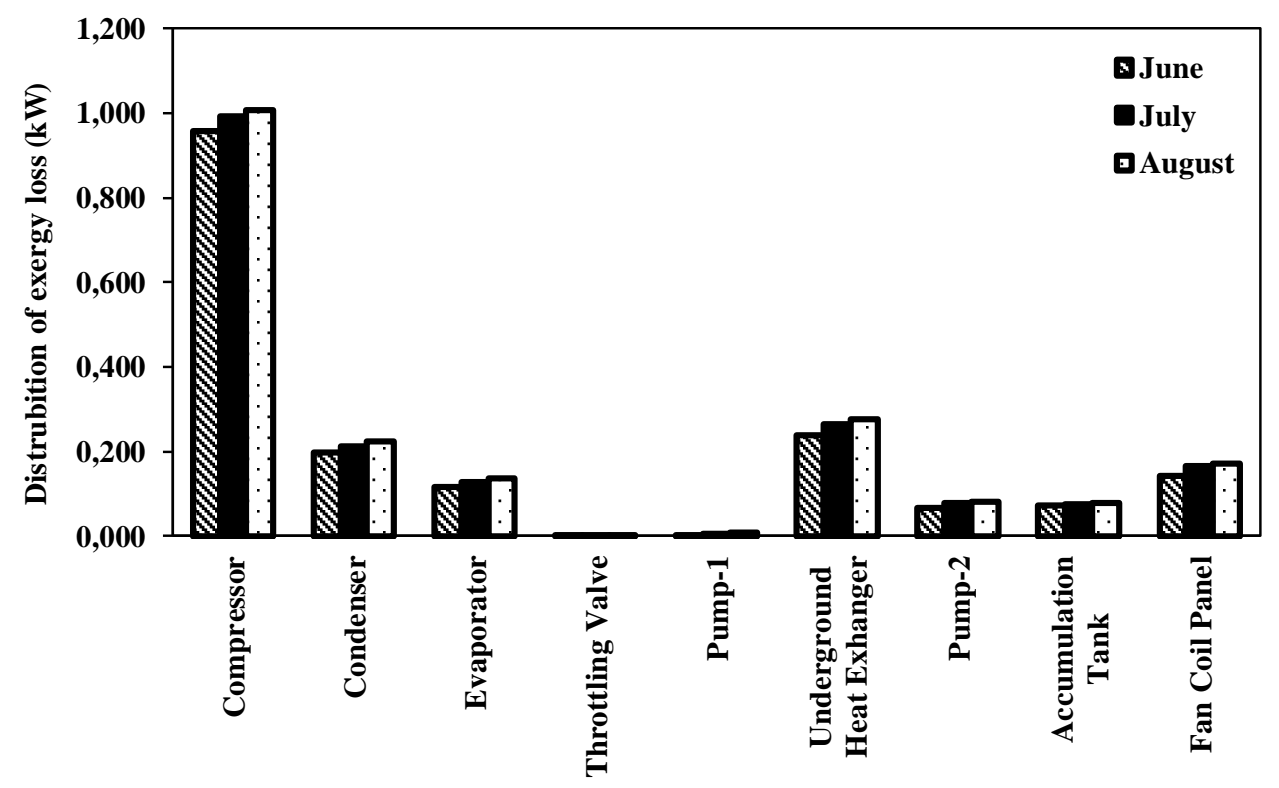

Figure 5. Monthly exergy loss of the system units in the summer.

When Figure 5 was examined, it was observed that the monthly exergy loss amounts of the system units increased in direct proportion to the external air temperature. Maximum amount of exergy loss occurred in the compressor by $0.985 \mathrm{~kW}$. The exergy loss rate values obtained by dividing the exergy loss amount in a unit of the horizontal type ground source heat pump cooling system in the summer by the amount of exergy loss in the whole system are presented in Figure 6.

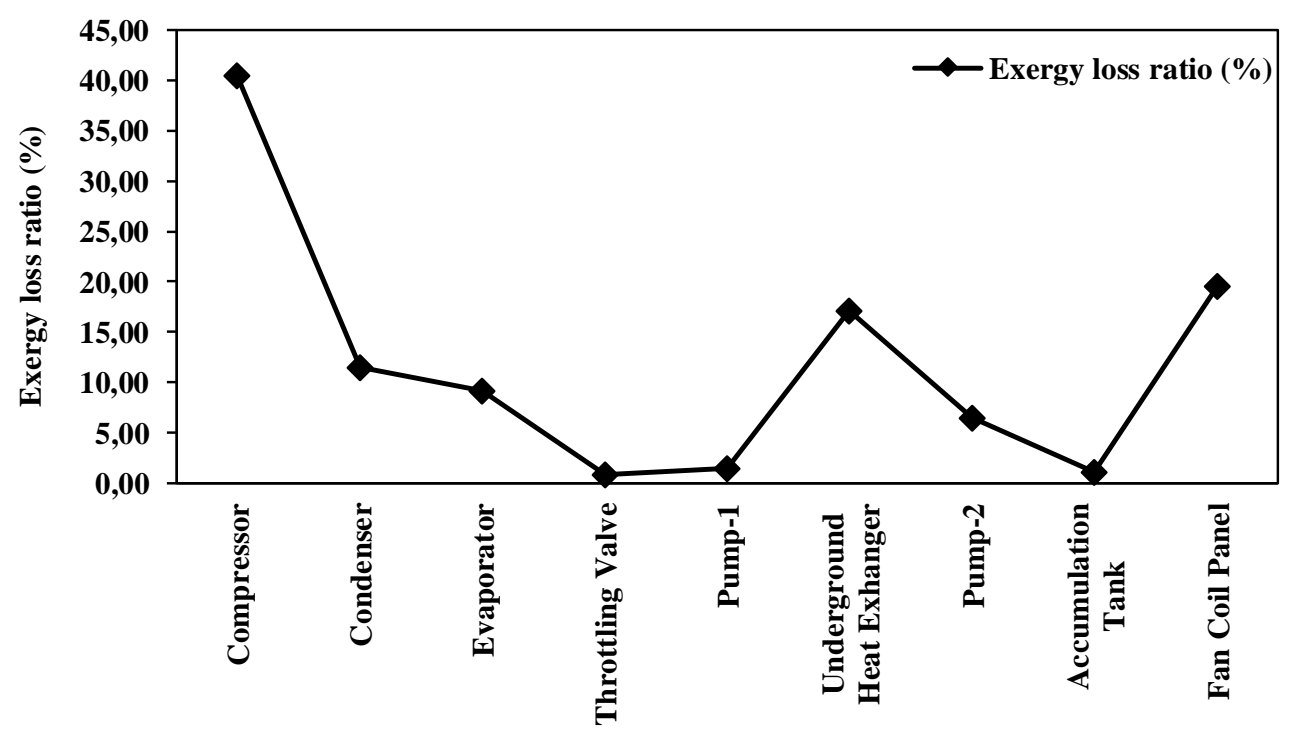

Figure 6. Exergy loss rates of the system units in the summer.

According to the assumptions and thermodynamic calculations made for the summer season in Figure 6 , the compressor in the system was the unit with the highest exergy loss rate by $40.51 \%$. In this context, exergy loss rates are among the parameters to be considered first in the improvements considered to be made in the horizontal type ground source heat pump cooling system. The improvements to be made in the unit with high exergy loss will decrease the exergy loss of the unit and also increase the exergy efficiency of the system. 


\section{Conclusions}

In the summer (01 June 2018 - 31 August 2018), the electricity consumption of the scroll type compressor used in the horizontal type ground source heat pump cooling system was affected in direct proportion to external air temperature, therefore, it was determined that scroll type compressor started to operate more at high air temperatures. In the analyses performed in this context, it was determined that system COP values were also affected in direct proportion to external air temperatures. During the summer season analyzed, the outside air temperature was measured as $26.5^{\circ} \mathrm{C}$ and $31.4^{\circ} \mathrm{C}$ on average, respectively, in June and August, that are the coldest and hottest months. The soil temperature at the depth of the well excavated as $2 \mathrm{~m}$ was measured as an average of $18.6^{\circ} \mathrm{C}$ in August, an average of $17.1^{\circ} \mathrm{C}$ in June and an average of $17.7^{\circ} \mathrm{C}$ in the summer. It was observed that the amount of energy transferred from the system to the soil varied between $8.04-8.45 \mathrm{~kW}$ in direct proportion to outside air temperature. The average amount of energy transferred from the system to the soil during the summer season was calculated as 8.30 $\mathrm{kW}$. Water was prepared at $12.50-14.25^{\circ} \mathrm{C}$ in the accumulation tank in order to meet the heat gain in the testing room during the summer season analyzed. In this process, the total amount of electricity consumed by the system from the meter (compressor, fan coil panel and circulation pumps) was measured as an average of $2.05 \mathrm{~kW}$. The energy drawn by the horizontal type ground source heat pump cooling system from the determined testing room varied between 9.23-9.66 $\mathrm{kW}$ and was affected in direct proportion to the change of the outside air temperature. Nevertheless, the COP value of the whole system was determined between 3.95-4.16.

When the exergy analysis results related to the units of the system examined during the summer season were evaluated, it was determined that the units with the highest exergy loss were compressor and evaporator, respectively. The units with the highest exergy loss rate in the system were compressor and fan coil panel. Although at first glance it appears that the energy loss in the evaporator was higher compared to the compressor, the exergy loss was much lower when compared to the compressor. Furthermore, when the energy efficiency and exergy efficiency were evaluated together as a result of the analyses performed in the system, the compressor stood out as the most inefficient unit. Therefore, the compressor should be considered first for the improvements to be planned. Considering these improvements, the first priority should be to evaluate the conditions that will allow the scroll type compressor to operate less often during system operation. For this purpose, the specified operating temperature ranges of the heat pump can be increased in the software of the system. Thus, the efficiency of the compressor of the horizontal type ground source heat pump, which is known to provide high thermal comfort in lower temperature regimes, will be increased. Thus, the system will be able to operate in lower temperature regimes for a longer period and the efficiency of the scroll type compressor will be increased. Along with the operation of the system in this way, both the exergy loss will be reduced and the electricity consumption will be further reduced. The improvements planned to be made in other system units should be as low-cost as possible and measures to reduce energy loss.

In conclusion, the system was observed to be very successful when it was considered in terms of reducing the energy consumption of the horizontal type ground source heat pump cooling system used for cooling, and more efficient use of energy in Diyarbakır province Bismil county, which usually meets its needs for air conditioning with primary energy sources. Nevertheless, energy is used more efficiently with the preference of such systems that can be alternative, and their usage is considered to be beneficial both in terms of economy and environmental protection. 


\section{References}

[1] Akan, A. E. ve Ünal, F.(2019). 4E Analysis of Thermal Power Plants, Theoretical Investigations and Applied Studies in Engineering, Chapter 17, 1st Edition, Ekin Publishing House, Turkey.

[2] Kıncay, O. ve Temir, G., (2002). "Economic Analysis of Soil and Air Source, Heat Pump Systems", Journal of Plumbing Engineering, 68: 31-37.

[3] Akbulut, U., Kıncay, O., Utlu, Z.,(2016).” Analysis of a wall cooling system using a heat pump", Renewable Energy, 85: 540-553

[4] Akbulut, U., Utlu, Z., Kıncay, O., (2016).” Exergoenvironmental and exergoeconomic analyses of a vertical type ground source heat pump integrated wall cooling system" Applied Thermal Engineering, 102: 904-921

[5] Akbulut, U., Utlu, Z., Kıncay, O., (2016).” Exergy, exergoenvironmental and exergoeconomic evaluation of a heat pump-integrated wall heating system, Energy, 107: 502-522

[6] Ünal, F., Temir, G., Köten, H., (2018). "Energy, exergy and exergoeconomic analysis of solarassisted vertical ground source heat pump system for heating season, Journal of Mechanical Science and Technology, 32(8): 3929-3942

[7] Ünal, F., Temir, G., (2014). "Exergoeconomic Analysis Of The Ground Source Heat Pump For Cooling Season In The Mardin Province", Sigma Journal of Engineering and Natural Sciences, 32: 477-488

[8] Hepbaşl1, A., Akdemir, O. ve Hancıŏlu, E.,(2003). "Experimental Study of a Closed Loop Vertical Ground Source Heat Pump System", Energy Conversion and Management, 44: 527548.

[9] Nagano, K., Katsura, T. ve Takeda, S., (2006). "Development of a Design and Performance Prediction Tool fort he Ground Source Heat Pum System”, Applied Thermal Engineering, 26: 1578-1592.

[10] Niğdelioğlu, O., (2006). Design of Earth Source Heat Pump and Techno-Economic Performance Analysis, Master Thesis, Dumlupınar University FBE, Kütahya.

[11] Özgener, Ö. ve Hepbaşl1, A., (2007). "Modeling and Performance Evaluation of Ground Source (Geothermal) Heat Pump Systems", Energy and Buildings, 39: 66-75.

[12] Karabacak, R., Acar, Ş., G., Kumsar, H., Gökgöz, A., Kaya, M. ve Tülek, Y., (2011). "Experimental investigation of the Cooling Performance of a Ground Source Heat Pump System in Denizli, Turkey", İnternational Journal of Refrigaration, 34: 454-465.

[13] Zhai, X., Q. Ve Yang, Y., (2011). "Experience on the Application of a Ground Source Heat Pump System in Archives Bilding", Energy and Buildings, 43: 3263-3270.

[14] Kılıç, İ., (2007). "Evaluation of Different Design Methods in Ground Source Heat Pumps", Journal of Ç.Ü. Engineering and Architecture Faculty,22(1):279-289.

[15] Ünal, F., Akan, A. E., (2017). "Thermodynamic Analysis of Heating with Solar Assisted Vertical Type Ground Source Heat Pump: Mardin Case Study", International Journal of Scientific and Technological Research, 3(2):1-8.

[16] Esen, H., (2007). Investigation of Seasonal Behavior of Vertical Pipe Soil Source Heat Pump in Residential Air Conditioning Systems, PHD Thesis, Firat University FBE, Elazığ.

[17] Isı, E., Bernt, H.K., Gök, M., (2017). "Second Law Analysis of A Gas Turbine of A LigniteFired Power Station" Science and Eng. J of Firat Univ., 29(2), 23-30. 